\title{
DNA Relatedness between Field Isolates of Mycoplasma F38 Group, the Agent of Contagious Caprine Pleuropneumonia, and Strains of Mycoplasma capricolum
}

\author{
FRANCOISE BONNET, ${ }^{1}$ COLETTE SAILLARD,${ }^{1}$ JOSEPH M. BOVÉ, ${ }^{1 *}$ RONALD H. LEACH, ${ }^{2}$ \\ DAVID L. ROSE, ${ }^{3}$ GEOFF S. COTTEW, ${ }^{4} \dagger$ AND JOSEPH G. TULLY ${ }^{3}$ \\ Laboratoire de Biologie Cellulaire et Moléculaire, Domaine de la Grande Ferrade, Institut National \\ de la Recherche Agronomique et Université de Bordeaux II, F-33883 Villenave d'Ornon, \\ France'; Mycoplasma Reference Laboratory, National Collection of Type Cultures, \\ Public Health Laboratory Service, London, England NW9 5HT ${ }^{2}$; Mycoplasma Section, \\ National Institute of Allergy and Infectious Diseases, Frederick, Maryland $21702^{3}$; \\ and Division of Animal Health, Commonwealth Scientific and \\ Industrial Research Organization, Parkville, Victoria, Australia ${ }^{4}$
}

\begin{abstract}
DNA-DNA hybridization experiments were carried out in order to clarify the taxonomic relationships between the F38 group of caprine mycoplasmas, the established etiologic agents of classical contagious caprine pleuropneumonia, and Mycoplasma capricolum, an organism associated with septicemia, arthritis, and mastitis in goats and sheep. The taxonomic status of the F38 group has been uncertain, principally because of the serological, genomic, and other properties which it shares with $M$. capricolum. Tritium-labeled DNAs from the $M$. capricolum type strain (California kid) and from prototype strain F38 were hybridized with unlabeled DNAs from these two strains and from four other isolates belonging to each group. The results showed consistent DNA relatedness values of about $70 \%$ between the F38 and $M$. capricolum groups, compared with levels of relatedness of about 90 and $85 \%$, respectively, for the strains within each group. In addition, the results of comparisons of these 10 strains in which growth inhibition and immunofluorescence tests were used confirmed the previously reported serological relationships between the two groups and reinforced other observations concerning their shared genomic and cell membrane characteristics, indicating that there is a close taxonomic relationship. However, as the $70 \%$ DNA relatedness values between the $M$. capricolum and F38 groups also indicate a degree of genomic difference inconsistent with a relationship at the species level, we conclude that our findings support previous proposals for classification of the $\mathbf{F 3 8}$ group as a subspecies of $M$. capricolum. In view of the prospective diagnostic problems, particularly those arising from the serological similarities of two putative subspecies, we believe that further studies should be performed to define additional phenotypic and genotypic properties that would allow more rapid and specific differentiation of the F38 group mycoplasmas.
\end{abstract}

Six mycoplasmas, several of which are associated with economically important diseases of ruminants, share a number of biologic properties critical for taxonomic characterization. These organisms, sometimes referred to as the Mycoplasma mycoides cluster, exhibit similar growth properties, morphology, biochemical activities, host specificity, pathogenicity, antigenic structure, cell membrane proteins, and genetic features (DNA homology) $(11,14,19,28,34)$. Two mycoplasmas in this cluster, Mycoplasma capricolum and the F38 group, present especially difficult problems regarding their taxonomic status and their accurate laboratory identification, as well as other questions related to such topics as quarantine and import-export control.

The name $M$. capricolum was first assigned (54) to an isolate (strain California $\mathrm{kid}^{\mathrm{T}}$ [ $\mathrm{T}=$ type strain]) obtained from a California goat herd in $1955(9,10) . M$. capricolum is now known to be an important pathogen that is associated with outbreaks of caprine mastitis, pneumonia, septicemia, and polyarthritis $(3,12,18,19,30)$ and with ovine arthritis and vulvovaginitis $(29,50)$ in many different geographic regions of the world. The organism has also been identified

\footnotetext{
* Corresponding author.

$\dagger$ Present address: Number 13, Oakland Court, Burleigh Waters, Queensland 4200, Australia.
}

in the middle ears and external ears of clinically normal goats $(15-17)$ and in alpine ibex (49).

For more than 25 years, from 1949 to about 1976, Mycoplasma mycoides subsp. capri was considered to be the etiologic agent of contagious caprine pleuropneumonia (CCPP) $(12,22)$. However, MacOwan and Minette (37) described studies performed in Kenya which established that a newly discovered mycoplasma (strain F38) could be consistently isolated from goats with classical CCPP. Subsequent work documented the repeated isolation of similar mycoplasmas from other field outbreaks of CCPP, established the ability of these organisms to induce experimental disease, and confirmed the contagious nature of contact infections with the organisms (38). F38-like organisms have now been reported from cases of CCPP in other parts of Africa $(26,35,42,45)$, in Oman, and (by implication) in Turkey (30). Strain F38 has also been isolated from sheep in Kenya (36).

Early laboratory analysis of strain F38 showed little serological cross-reactivity with other recognized caprine-ovine mycoplasmas (23), and the isoenzyme patterns of F38 were reported to be different from those of other mycoplasmas (48). However, more extensive characterization revealed significant relationships, including considerable serological cross-reactivity, between strain F38 and the type strain of $M$. capricolum, as well as with representative strain PG50 of 
TABLE 1. Strains used in this study

\begin{tabular}{llll}
\hline \multicolumn{1}{c}{ Strain } & \multicolumn{1}{c}{ Received from: } & \multicolumn{1}{c}{ Origin } \\
\hline $\begin{array}{l}\text { M. capricolum } \text { strains } \\
\text { California kid }{ }^{\mathrm{T}}\left(=\text { NCTC } 10154^{\mathrm{T}}\right)\end{array}$ & NCTC & Grinine reaction \\
$74 / 3220$ & G. S. Cottew & Goat, California & \multicolumn{1}{c}{ Positive } \\
$2712 / 77$ & G. S. Cottew & Goat, Australia & Weakly positive \\
M4528/76 (= Swanepoel 490/73) & G. S. Cottew & Sheep, Zimbabwe & Positive \\
GM262G & A. J. DaMassa & Goat, United States & Positive \\
F38-like strains & NCTC & Gositive \\
F38 (MacOwan) (= NCTC 10192) & F. Rurangirwa and A. Kibor & Goat, Kenya & Negative \\
G1943/80 & F. Rurangirwa and A. Kibor & Goat, Kenya & Negative \\
G94/83 & F. Rurangirwa and A. Kibor & Goat, Kenya & Negative \\
G280/80 & G. Jones & Goat (from Turkey), Oman & Negative \\
7/1a & & & Negative \\
\hline
\end{tabular}

${ }^{a}$ NCTC, National Collection of Type Cultures.

an unclassified mycoplasma, bovine group 7 (24). In a further examination of the genomic relationships of F38, California $\mathbf{k i d}^{\mathrm{T}}$, and PG50, Christiansen and Ernø (6) observed DNA homology levels of $80 \%$ between strains F38 and California $\mathrm{kid}^{\mathrm{T}}$ and about $60 \%$ between either of these two strains and PG50. Since that time, many other reports have confirmed the close relationship of F38-like isolates and $M$. capricolum strains; the data include additional serologic data $(3,31,46)$ and similarities in cell membrane protein patterns as determined by polyacrylamide gel electrophoresis (PAGE) $(1,11$, 44), DNA methylation pattern data (2), genetic restriction fragment length polymorphism data (7), data from crosshybridization studies performed with various DNA probes $(20,52)$, and cross-immunization test data (32).

The apparently close relationship between strain F38 and an established Mycoplasma species led to questions concerning the proper taxonomic designation of this strain. The International Committee on Systematic Bacteriology Subcommittee on the Taxonomy of Mollicutes began discussions on the taxonomic status of F38 at an interim meeting in 1984 (27), where it endorsed the recommendation (24) that fresh field isolates belonging to the F38 group and $M$. capricolum should be compared in DNA-DNA hybridization and PAGE pattern tests. In addition, the subcommittee convened an ad hoc advisory group to review taxonomic, pathogenicity, and quarantine problems associated with the six bovine, caprine, and ovine mycoplasmas that make up the $M$. mycoides cluster, including F38 and $M$. capricolum. A report by this advisory group in $1986(14,28)$ recommended that the first priority should be to resolve the taxonomic position of F38 and suggested that additional DNA-DNA hybridization tests should include new field isolates belonging to both the F38 group and $M$. capricolum. Such tests have been carried out, and the results are reported here, together with the results of some additional serological tests.

\section{MATERIALS AND METHODS}

Mycoplasmas. The origins and designations of the strains belonging to the $M$. capricolum and F38 groups used in this study are shown in Table 1. Strain California kid (= NCTC $10154^{\mathrm{T}}$ ) of $M$. capricolum was derived from the original strain deposited in the American Type Culture Collection (ATCC 27343) as the type strain of the species. Strain F38 (= NCTC 10192) is the original Kenyan isolate that was submitted by $K$. J. MacOwan to the National Collection of Type Cultures. Another line of this strain (AMRC-C758), which was used in some of the serologic studies described below, came from the culture collection of the Institute for Medical Microbiology, Aarhus, Denmark, and was received through the courtesy of Eyvind Freundt. Strain M4528/76 of $M$. capricolum was isolated from a sheep in Zimbabwe (50), and the other three strains of $M$. capricolum were isolated from goats in widely separated areas of Australia (74/3220 and 2712/77) and the United States (GM 262G) (17). The F38-like isolate designated $7 / 1$ a was obtained from a recently imported Turkish goat in Oman (30), and the other three F38-like strains were recent Kenyan isolates obtained directly from F. Rurangirwa and A. Kibor. Some serological tests were also performed with $M$. capricolum GM13, an organism recovered in 1982 (16) from the stifle joint of a California goat kept frozen from the original studies of Cordy et al. $(9,10)$.

All strains were initially collected at the National Collection of Type Cultures and were filter cloned three times after receipt by using 220-nm-pore-size membrane filters for $M$. capricolum strains and 450-nm-pore-size filters for F38-like strains. Replicate cultures were lyophilized and distributed to the participating laboratories for both hybridization and serologic analysis.

Culture media. Broth and agar media containing $20 \%$ horse serum (11) were used in the initial filtration and cloning procedures, while the SP-4 broth formulation (56) was used to prepare cell pellets for DNA extraction and in serologic tests.

Metabolic activities. Tests to determine the ability of strains to ferment glucose and hydrolyze arginine were carried out by using standard procedures (13).

Genomic analysis. Mycoplasma strains were grown in 500 to $1,000 \mathrm{ml}$ of SP-4 broth and were pelleted by centrifugation. The methods used for extraction and purification of mycoplasmal DNA were similar to procedures described previously (5). The DNA-DNA hybridization techniques used have also been described previously (21). Briefly, hybridization was carried out in buffer containing $0.4 \mathrm{M}$ $\mathrm{NaCl}$ and $50 \%$ formamide for $60 \mathrm{~h}$ either at $38^{\circ} \mathrm{C}\left(12^{\circ} \mathrm{C}\right.$ below the melting temperature $)$ or at $30^{\circ} \mathrm{C}\left(20^{\circ} \mathrm{C}\right.$ below the melting temperature). Hybrids were then analyzed by scintillation counting after treatment with $\mathrm{S} 1$ nuclease.

Serologic analysis. Comparisons of the test strains by growth inhibition (GI) tests were carried out mainly in Frederick, Md., by using conventional techniques (8). These GI tests were performed with polyclonal antisera (prepared locally in rabbits) to $M$. capricolum California $\mathrm{kid}^{\mathrm{T}}$ (= NCTC $10154^{\mathrm{T}}$ ) and GM13 and F38-like strain AMRC-C758. In addi- 
tion, polyclonal antisera to several other caprine and bovine mycoplasma strains were used in these tests; including antisera to the following organisms (homologous GI zone diameters are given in parentheses): $M$. mycoides subsp. mycoides (small-colony biotype strain) PG1 (9 mm); M. mycoides subsp. mycoides (large-colony form strains) UM30847 (2 mm) and B3 $(5 \mathrm{~mm}) ; M$. mycoides subsp. capri PG3 (10 mm); Mycoplasma agalactiae PG2 (2 mm); and Mycoplasma putrefaciens KS-1 $(9 \mathrm{~mm})$. A monoclonal antiserum to F38, prepared and kindly supplied through the courtesy of F. R. Rurangirwa, Nairobi, Kenya, was also used in London, United Kingdom, to confirm the identity of F38-like strains in GI tests.

Direct immunofluorescence tests on agar colonies of the various $M$. capricolum and F38-like strains were also carried out in Frederick, Md., with conjugated antisera to $M$. capricolum GM13 and strain F38. Seven twofold dilutions (from 1:8 to 1:512) of each of the conjugates were prepared in phosphate-buffered saline. Fourteen SP-4 agar pieces containing colonies of each strain were removed from plates and placed on individual glass slides. Each agar section was stained with one dilution of each of the two conjugates and then examined microscopically under incident illumination with UV light (25). The extinction titer, representing the last twofold dilution of the conjugate that produced immunofluorescence of agar colonies, was determined for each strain. The conjugate to $M$. capricolum GM13 had a homologous extinction titer of 128 , and the homologous extinction titer of the F38 conjugate was 64 .

\section{RESULTS}

Metabolic activities. All $M$. capricolum strains grew rapidly on conventional horse serum media and exhibited strong acidification of glucose-containing broth after incubation at $37^{\circ} \mathrm{C}$ for 1 to 2 days. All strains also exhibited active arginine hydrolysis (strain 74/3220 gave a weak, but nevertheless positive, reaction in this test). In contrast, the members of the F38 group were much more fastidious and grew more slowly in such media. Some strains were very slow to produce acidification of glucose broth, requiring incubation for up to 10 days. Neither strain F38 nor the recent field isolates exhibited a positive test for arginine hydrolysis (Table 1). Some F38-like strains appeared to grow much better in specialized media, such as SP-4.

Genomic analysis. In hybridization experiments (Table 2), tritium-labeled DNAs from $M$. capricolum California kid ${ }^{\mathrm{T}}$ and strain F38 were used as DNA probes with unlabeled DNAs from these two strains and from the eight field isolates. Reactions were carried out under both high-stringency conditions $\left(38^{\circ} \mathrm{C}\right)$ and low-stringency conditions $\left(30^{\circ} \mathrm{C}\right)$. The experiments performed with labeled and unlabeled DNAs from each of the two control organisms yielded hybridization values of 84 to $85 \%$ under the high-stringency conditions, and these values were normalized to $100 \%$. When labeled DNA from $M$. capricolum California kid ${ }^{\mathrm{T}}$ was hybridized with DNAs from other $M$. capricolum strains, relatedness values of 82 to $87 \%$ were obtained under highstringency conditions. In contrast, under the same conditions, strain F38 and other F38-like isolates exhibited only 67 to $71 \%$ hybridization with this probe. Reciprocal testing with the labeled F38 probe produced similar results, indicating that the levels of relatedness between F38 and F38-like strains were approximately 87 to $89 \%$, while the levels of relatedness with the five $M$. capricolum strains were only 67 to $73 \%$ (Table 2).
TABLE 2. Levels of homology between $M$. capricolum or F38 DNA and DNAs from mycoplasma field isolates under various conditions ${ }^{a}$

\begin{tabular}{|c|c|c|c|c|}
\hline \multirow{3}{*}{ Unlabeled DNA from: } & \multicolumn{4}{|c|}{$\begin{array}{l}\% \text { of hybridization with tritium-labeled } \\
\text { DNA from: }\end{array}$} \\
\hline & \multicolumn{2}{|c|}{$\begin{array}{l}\text { M. capricolum } \\
\text { California kid }\end{array}$} & \multicolumn{2}{|c|}{$\begin{array}{c}\text { Mycoplasma strain } \\
\text { F38 }\end{array}$} \\
\hline & $38^{\circ} \mathrm{C}$ & $30^{\circ} \mathrm{C}$ & $38^{\circ} \mathrm{C}$ & $30^{\circ} \mathrm{C}$ \\
\hline \multicolumn{5}{|l|}{ M. capricolum strains } \\
\hline NCTC $10154^{\mathrm{T}}$ & $100(84)^{b}$ & $100(74)$ & 69 & 74 \\
\hline $2712 / 77$ & 85 & 88 & 67 & 78 \\
\hline M4528/76 & 84 & 91 & 73 & 81 \\
\hline $74 / 3220$ & 82 & 88 & 70 & 75 \\
\hline GM262G & 87 & 90 & 68 & 78 \\
\hline \multicolumn{5}{|c|}{ Mycoplasma F38-like strains } \\
\hline F38 (= NCTC 10192) & 68 & 77 & $100(85)$ & $100(87)$ \\
\hline G1943/80 & 71 & 74 & 87 & 89 \\
\hline $\mathrm{G} 280 / 80$ & 71 & 74 & 87 & 92 \\
\hline G94/83 & 67 & 78 & 88 & 89 \\
\hline $7 / 1 \mathrm{a}$ & 71 & 76 & 89 & 92 \\
\hline \multicolumn{5}{|l|}{ Controls } \\
\hline Escherichia coli $\mathrm{C} 600$ & 7 & 8 & 8 & 9 \\
\hline Herring sperm & 8 & 8 & 7 & 7 \\
\hline
\end{tabular}

$a$ The following conditions were used. Preparations were hybridized in buffer containing $0.4 \mathrm{M} \mathrm{NaCl}$ and $50 \%$ formamide for $16 \mathrm{~h}$ either at $38^{\circ} \mathrm{C}\left(12^{\circ} \mathrm{C}\right.$ below the melting temperature $)$ or at $30^{\circ} \mathrm{C}\left(20^{\circ} \mathrm{C}\right.$ below the melting temperature). The hybrids were then analyzed by scintillation counting after treatment with $S 1$ nuclease. The averages of two experiments are shown.

${ }^{b}$ The experimental hybridization values for the homologous fractions (values in parentheses) were defined as $100 \%$ homology.

Serologic analysis. Conventional GI tests performed with polyclonal antiserum to either $M$. capricolum California kid $^{\mathrm{T}}$ or strain F38 revealed no cross-reactivity between these two prototype strains, but when the antisera to these two strains were tested against all other isolates, there were considerable cross-reactions between the two groups (Table 3). Although most of the F38-like strains appeared to exhibit quantitatively more inhibition against the F38 antiserum,

TABLE 3. Results of GI tests performed with field isolates of M. capricolum and mycoplasma strain $\mathrm{F} 38^{a}$

\begin{tabular}{lll}
\hline \multicolumn{1}{c}{ Strain } & \multicolumn{2}{c}{$\begin{array}{c}\text { Diam (mm) of GI zone with } \\
\text { antiserum to: }\end{array}$} \\
\cline { 2 - 3 } & $\begin{array}{c}\text { M. capricolum } \\
\text { California kid }\end{array}$ & $\begin{array}{c}\text { Mycoplasma } \\
\text { strain F38 }\end{array}$ \\
\hline M. capricolum strains & & \\
California kid ${ }^{\mathrm{T}}$ (= NCTC 10154 $\left.{ }^{\mathrm{T}}\right)$ & 4 & 0 \\
74/3220 & $2(\mathrm{P})^{b}$ & $2(\mathrm{P})$ \\
GM262G & $2(\mathrm{P})$ & 4 \\
M4528/76 & 0 & $2(\mathrm{P})$ \\
2712/77 & 0 & 0 \\
F38-like strains & & \\
F38 (= NCTC 10192) & 0 & 5 \\
$7 / 1 a$ & 0 & 5 \\
G94/83 & 4 & 6 \\
G280/80 & $2(\mathrm{P})$ & 6 \\
G1943/80 & $4(\mathrm{P})$ & 7 \\
\hline
\end{tabular}

${ }^{a}$ All strains were negative in GI tests performed with antisera prepared against cow-derived $M$. mycoides subsp. mycoides PGI (small-colony form) and the following goat-derived strains: $M$. mycoides subsp. mycoides UM30847 and B3 (both large-colony forms); $M$. agalactiae PG2; $M$. mycoides subsp. capri PG3; and $M$. putrefaciens KS-1.

${ }^{b} \mathrm{P}$, zones of partial inhibition with some breakthroughs of mycoplasma colonies within measured zones of inhibition. 
TABLE 4. Results of agar plate colony immunofluorescence tests performed with field isolates of $M$. capricolum and mycoplasma strain F38

\begin{tabular}{|c|c|c|}
\hline \multirow[t]{2}{*}{ Strain } & \multicolumn{2}{|c|}{$\begin{array}{l}\text { Reciprocal extinction immu- } \\
\text { nofluorescence titer for agar } \\
\text { colonies treated with dilutions } \\
\text { of conjugated antiserum to: }\end{array}$} \\
\hline & $\begin{array}{l}\text { M. capri- } \\
\text { colum } \\
\text { GM13 }\end{array}$ & $\begin{array}{c}\text { Mycoplasma } \\
\text { strain } \\
\text { F38 }\end{array}$ \\
\hline \multicolumn{3}{|l|}{ M. capricolum strains } \\
\hline GM13 & 128 & 16 \\
\hline California kid ${ }^{\mathrm{T}}\left(=\right.$ NCTC $\left.10154^{\mathrm{T}}\right)$ & 32 & 32 \\
\hline $74 / 3220$ & 32 & 16 \\
\hline GM262G & 32 & $<8$ \\
\hline M4528/76 & 128 & 8 \\
\hline $2712 / 77$ & 32 & 16 \\
\hline \multicolumn{3}{|l|}{ Mycoplasma F38-like strains } \\
\hline F38 (= NCTC 10192) & $<8$ & 64 \\
\hline $7 / 1 a$ & $<8$ & 32 \\
\hline G94/83 & $<8$ & 64 \\
\hline G280/80 & $<8$ & 64 \\
\hline G1943/80 & $<8$ & 64 \\
\hline
\end{tabular}

three of the four strains in the group were also inhibited by the $M$. capricolum antiserum. None of the $M$. capricolum field isolates was clearly identified with $M$. capricolum antiserum; these isolates either failed to be inhibited by this antiserum or demonstrated only as much inhibition with this antiserum as they demonstrated with the F38 antiserum. All strains tested against other mycoplasma antisera in GI tests were negative ('Table 3 ).

The direct immunofluorescence tests appeared to be more successful for separating isolates belonging to the two groups. All field isolates of $M$. capricolum reacted with a conjugate to $M$. capricolum GM13 at extinction titers of 32 to 128 , while none of the isolates belonging to the F38 cluster of strains was stained with a 1:8 dilution of the conjugate (Table 4). The F38 conjugate produced more consistent staining of F38-like isolates (extinction titers ranged from 32 to 64), whereas most $M$. capricolum strains reacted at levels of $<8$ to 16; the exception was the type strain, which gave an extinction titer of 32 .

\section{DISCUSSION}

The results of this study again $(6,7,20,23,24,52)$ emphasize that the F38-like mycoplasmas, the well-documented causative agents of caprine pleuropneumonia (37, 38 ), share a considerable number of genomic and serological properties with a variety of $M$. capricolum strains of caprine or ovine origin. The DNA-DNA hybridization data reported here, which were obtained under high-stringency conditions, indicate that the level of DNA relatedness between prototype strain F38 and the type strain of $M$. capricolum is about $70 \%$. The inclusion of four field isolates belonging to each group in the comparison did not significantly alter this level of relatedness. Our values are somewhat lower than, although fairly close to, the previously reported level of relatedness between F38 and California kid ${ }^{T}$ (80\%) (6) and seem to suggest that there is a genomic relationship somewhat below the species level.

Some other shared genomic properties of these two clusters have been reported previously. $M$. capricolum strain California $\mathrm{kid}^{\mathrm{T}}$ and strain $\mathrm{F} 38$ have similar DNA base compositions ( 24 to 25 mol\% guanine plus cytosine) $(6,41)$, and most $M$. capricolum strains (not including the type strain) and F38-like strains have DNAs with methylated adenine, as determined by selective restriction endonuclease digestions (2). Restriction enzyme mapping of the two groups was also reported recently by Christiansen and Ernø (7), who found that all of the strains of both groups tested exhibited identical restriction enzyme cleavage sites within the two rRNA genes, although the cleavage sites outside these genes varied. In this locus, F38-like strains had a pattern of HindIII and EcoRI sites distinct enough for the authors to propose that the pattern might allow specific identification. Various $M$. capricolum strains exhibited a different pattern of restriction sites within these areas. Furthermore, in a more recent genomic mapping study of both groups of organisms, Whitley (57) concluded that there was "insufficient similarity or differences" to distinguish the two groups. More recently, reports on the use of genomic probes to differentiate these organisms have appeared. Dedieu and colleagues (20) developed a species-specific DNA probe for $M$. capricolum California $\mathrm{kid}^{\mathrm{T}}$ by using a 900-kbp RsaI fragment in dot blot hybridization. The probe did not hybridize with the DNA of a bovine group 7 strain or with the DNA of strain F38 and was capable of detecting $M$. capricolum in the milk of naturally infected goats. Likewise, Taylor and coworkers (52) reported the use of a cloned EcoRI fragment from F38 DNA that distinguished F38 from $M$. capricolum and bovine group 7 strains. Although these probes have yet to be applied to clinical isolates in areas where F38 and $M$. capricolum are endemic, they offer important advances in specific differentiation of the three mycoplasmas.

The genome sizes of F38 $(1,064 \mathrm{~kb})$ and California kid $^{\mathrm{T}}$ $(1,070$ to $1,120 \mathrm{~kb})$ are similar $(40,57)$. However, the clear distinction in DNA relatedness values that we found between the F38 and $M$. capricolum groups (ca. 85 to $90 \%$ for each group) is consistent with earlier recommendations $(6$, 14) that F38 and related strains warrant subspecies status within $M$. capricolum.

Our serological findings also reinforce the results of other published work on the serological cross-reactivity between the two mycoplasma clusters. Diagnostic serological differentiation of group F38 organisms from $M$. capricolum and even from bovine group 7 strains will continue to be a problem. This difficulty is exemplified by the recent report concerning F38-like mycoplasmas that were isolated from milk of mastitic cows in India (33). The authors of this report did not indicate clearly how these organisms were characterized serologically, but current knowledge suggests that F38 is not likely to be actively involved in cows. Bovine group 7 strains, which exhibit serological cross-reactivity with F38, could be misidentified as caprine mycoplasmas in this situation, as has been noted elsewhere (53). Crossreactivity between bovine group 7 strains and $M$. capricolum might also account for reports of the latter organism in bovine semen and in cases of bovine mastitis $(4,51)$.

Some general observations might help to stimulate comparative studies on the biologic and serologic properties of the two putative subspecies of $M$. capricolum (and perhaps of bovine group 7 strains). Additional phenotypic differences are certainly needed to allow better separation and identification within these groups. There are obvious differences in growth and metabolic activity between F38-like strains and $M$. capricolum isolates; the former are more fastidious, grow more slowly, and are difficult to adapt to broth or agar media. The inability of F38 strains to hydrolyze arginine is a 
potentially important property for identification, because most $M$. capricolum strains have metabolic pathways for both glucose and arginine (54). Further comparisons of the growth and other metabolic markers of F38 and $M$. capricolum strains seem to be warranted.

A variety of serologic techniques have been applied to field diagnosis of CCPP, including complement fixation (37), passive hemagglutination (39), enzyme-linked immunosorbant assays (ELISA) (55), and latex agglutination tests (45, 47). However, few comparisons have been made between CCPP isolates and known strains of $M$. capricolum. Kibe and colleagues (31) described an ELISA that could distinguish F38 and $M$. capricolum strains, whereas two-way cross-reactivity was seen between F38 and bovine group 7 . Immunoblotting showed that F38 and $M$. capricolum strains are closely related, sharing at least four major protein antigens.

Rurangirwa and colleagues (47) have used a monoclonal antibody to F38 with apparently sufficient specificity to provide useful separation of F38 strains from $M$. capricolum and bovine group 7 strains by a modified GI test. Successful identification of 13 different F38 isolates was reported. Further testing of this reagent and procedure with additional field isolates seems desirable.

Notwithstanding the veterinary diagnostic problems and the newly developed potential for identifying F38 by a variety of means, the results of our genomic studies indicate clearly that F38 is taxonomically closely related to, but separate from, the currently described strains of $M$. capricolum. There may be eventual justification for the classification of F38-like strains as a subspecies of $M$. capricolum. The incidental finding of a close serological relationship between F38 and bovine group 7 strains remains to be addressed. This does not present an immediate taxonomic problem, since this group of bovine mycoplasmas has not been given formal taxonomic status. Additional DNA relatedness studies, such as those now in progress involving all six members of the $M$. mycoides cluster (43), may help clarify these relationships.

\section{ACKNOWLEDGMENT}

We thank A. J. DaMassa for his comments and critical review of the manuscript.

\section{REFERENCES}

1. Andersen, H., G. Christiansen, and C. Christiansen. 1984. Electrophoretic analysis of proteins from Mycoplasma capricolum and related serotypes using extracts from intact cells and from minicells containing cloned Mycoplasma DNA. J. Gen. Microbiol. 130:1409-1418.

2. Bergemann, A. D., J. C. Whitley, and L. R. Finch. 1990. Taxonomic significance of differences in DNA methylation within the "Mycoplasma mycoides cluster" detected with restriction endonucleases $M b o I$ and $D p n I$. Lett. Appl. Microbiol. 11:48-51.

3. Bölske, G., H. Msami, N. E. Humlesjö, H. Ernø, and L. Jönsson. 1988. Mycoplasma capricolum in an outbreak of polyarthritis and pneumonia in goats. Acta Vet. Scand. 29:331-338.

4. Breard, A., and F. Poumarat. 1988. Isolement de Mycoplasma capricolum á partir d'un sperme de taureau. Rev. Elev. Med. Vet. Pays Trop. 41:149-150.

5. Carle, P., C. Saillard, and J. M. Bové. 1983. DNA extraction and purification. Methods Mycoplasmol. 1:295-299.

6. Christiansen, C., and H. Ernø. 1982. Classification of the F38 group of caprine mycoplasma strains by DNA hybridization. $\mathrm{J}$. Gen. Microbiol. 128:2523-2526.

7. Christiansen, G., and H. Ernø. 1990. RFLP in rRNA genes of Mycoplasma capricolum, the caprine F38-like group and bovine serogroup 7. Zentralbl. Bakteriol. Suppl. 20:479-488.

8. Clyde, W. A., Jr. 1983. Growth inhibition tests. Methods Mycoplasmol. 1:405-410.

9. Cordy, D. R., and H. E. Adler. 1960. Patterns of reaction in infection with a virulent form of pleuropneumonia-like organism from goats. Ann. N. Y. Acad. Sci. 79:686-695.

10. Cordy, D. R., H. E. Adler, and R. Yamamoto. 1955. A pathogenic pleuropneumonialike organism from goats. Cornell Vet. 45:50-68.

11. Costas, M., R. H. Leach, and D. L. Mitchelmore. 1987. Numerical analysis of PAGE protein patterns and the taxonomic relationships within the "Mycoplasma mycoides cluster." J. Gen. Microbiol. 133:3319-3329.

12. Cottew, G. S. 1979. Caprine-ovine mycoplasmas, p. 103-132. In J. G. Tully and R. F. Whitcomb (ed.), The mycoplasmas, vol. 2. Human and animal mycoplasmas. Academic Press, Inc., New York.

13. Cottew, G. S. 1983. Recovery and identification of caprine and ovine mycoplasmas. Methods Mycoplasmol. 2:91-104.

14. Cottew, G. S., A. Breard, A. J. DaMassa, H. Ernø, R. H. Leach, P. C. Lefevre, A. W. Rodwell, and G. R. Smith. 1987. Taxonomy of the Mycoplasma mycoides cluster. Isr. J. Med. Sci. 23:632 635.

15. Cottew, G. S., and F. R. Yeats. 1981. Occurrence of mycoplasmas in clinically normal goats. Aust. Vet. J. 57:52-53.

16. DaMassa, A. J. 1983. Prevalence of mycoplasmas and mites in the external auditory meatus of goats. Calif. Vet. 37:10-13, 17

17. DaMassa, A. J. 1990. The ear canal as a culture site for demonstration of mycoplasmas in clinically normal goats. Aust. Vet. J. 67:267-269.

18. DaMassa, A. J., D. L. Brooks, H. E. Adler, and D. E. Watt. 1983. Caprine mycoplasmosis: acute pulmonary disease in newborn kids given Mycoplasma capricolum orally. Aust. Vet. J. 60:125-126.

19. DaMassa, A. J., P. S. Wakenell, and D. L. Brooks. 1992. Mycoplasmas of goats and sheep. J. Vet. Diagn. Invest. 4:101113.

20. Dedieu, L., A. Breard, and P. C. Lefevre. 1992. Development of a species-specific DNA probe for Mycoplasma capricolum. Vet. Microbiol. 32:189-197.

21. Degorce-Dumas, J. R., B. Ricard, and J. M. Bové. 1983. Hybridization between mycoplasma DNAs. Methods Mycoplasmol. 1:319-325.

22. Edward, D. F. ff. 1953. Organisms of the pleuropneumoniae group causing disease in goats. Vet. Rec. 49:873-875.

23. Ernø, H., R. H. Leach, and K. J. MacOwan. 1979. Further characterization of mycoplasma strain F38. Trop. Anim. Health Prod. 11:84.

24. Ernø, H., R. H. Leach, M. M. Salih, and K. J. MacOwan. 1983. The F38-like group, a new group of caprine mycoplasmas? Acta Vet. Scand. 24:275-286.

25. Gardella, R. S., R. A. Del Giudice, and J. G. Tully. 1983 Immunofluorescence. Methods Mycoplasmol. 1:431-439.

26. Harbi, M. S. M. A., M. A. El Tahir, K. J. MacOwan, and A. A. Nayil. 1981. Mycoplasma strain F38 and contagious caprine pleuropneumonia in the Sudan. Vet. Rec. 108:261.

27. International Committee on Systematic Bacteriology Subcommittee on the Taxonomy of Mollicutes. 1985. Minutes of interim meeting, 21 and 26 June 1984, Jerusalem, Israel. Int. J. Syst. Bacteriol. 35:378-381.

28. International Committee on Systematic Bacteriology Subcommittee on the Taxonomy of Mollicutes. 1988. Minutes of interim meeting, 25 and 28 August 1986, Birmingham, Alabama. Int. J. Syst. Bacteriol. 38:226-230.

29. Jones, G. E., A. G. Rae, S. A. Lister, J. M. W. Jones, G. S. Grater, and N. Richards. 1983. Isolation of exotic mycoplasmas from sheep in England. Vet. Rec. 113:540.

30. Jones, G. E., and A. R. Wood. 1988. Microbiological and serological studies on caprine pneumonias in Oman. Res. Vet. Sci. 44:125-131.

31. Kibe, M. K., D. E. Bidwell, P. Turp, and G. R. Smith. 1985. Demonstration of cross-reactive antigens in F38 and related mycoplasmas by enzyme-linked immunosorbent assay (ELISA) 
and immunoblotting. J. Hyg. 95:95-106.

32. Kibe, M. K., and G. R. Smith. 1984. A study of F38-type and related mycoplasmas by mycoplasmaemia and cross-immunization tests in mice. J. Hyg. 93:465-473.

33. Kumar, A., and D. N. Garg. 1991. Isolation of mycoplasma F38 from the milk of mastitic cows. Vet. Rec. 128:429.

34. Leach, R. H., M. Costas, and D. L. Mitchelmore. 1989. Relationship between Mycoplasma mycoides subsp. mycoides ("large-colony" strains) and M. mycoides subsp. capri, as indicated by numerical analysis of one-dimensional SDS-PAGE protein patterns. J. Gen. Microbiol. 135:2993-3000.

35. Lefevre, P. C., A. Breard, A. Alfarouk, and S. Buron. 1987 Mycoplasma species F38 isolated in Chad. Vet. Rec. 121:575.

36. Litamoi, J. K., S. W. Wanyangu, and P. K. Simam. 1990 Isolation of Mycoplasma biotype F38 from sheep in Kenya. Trop. Anim. Health Prod. 22:260-262.

37. MacOwan, K. J., and J. E. Minette. 1976. A mycoplasma from acute contagious caprine pleuropneumonia in Kenya. Trop. Anim. Health Prod. 8:91-95.

38. MacOwan, K. J., and J. E. Minette. 1977. The role of mycoplasma strain F38 in contagious caprine pleuropneumonia (CCPP) in Kenya. Vet. Rec. 101:380-381.

39. Muthomi, E. K., and F. R. Rurangirwa. 1983. Passive haemagglutination and complement fixation as diagnostic tests for contagious caprine pleuropneumonia caused by the F38 strain of mycoplasma. Res. Vet. Sci. 35:1-4.

40. Neimark, H. C., and C. S. Lange. 1990. Pulse-field electrophoresis indicates full-length mycoplasma chromosomes range widely in size. Nucleic Acids Res. 18:5443-5448.

41. Neimark, H. C., and J. J. Pene. 1965. Characterization of pleuropneumonia-like organisms by deoxyribonucleic acid composition. Proc. Soc. Exp. Biol. Med. 118:517-519.

42. Perreau, P., A. Breard, and C. Le Goff. 1984. Infection expérimentale de la chévre par les souches de mycoplasme de type F.38 (pleuropneumonie contagieuse caprine). Ann. Microbiol. (Paris) 135A:119-124.

43. Pitcher, D., and R. H. Leach. Personal communication.

44. Rodwell, A. W. 1982. The protein fingerprints of mycoplasmas. Rev. Infect. Dis. 4:S8-S17.

45. Rurangirwa, F. R., B. Kouyate, M. Niang, and T. C. McGuire.
1990. CCPP: antibodies to F38 polysaccharide in Mali goats. Vet. Rec. 127:353.

46. Rurangirwa, F. R., T. C. McGuire, A. Kibor, and S. Chema 1987. A latex agglutination test for field diagnosis of contagious caprine pleuropneumonia. Vet. Rec. 121:191-193.

47. Rurangirwa, F. R., T. C. McGuire, A. J. Musoke, and A. Kobor. 1987. Differentiation of F38 mycoplasmas causing contagious caprine pleuropneumonia with a growth-inhibiting monoclonal antibody. Infect. Immun. 55:3219-3220.

48. Salih, M. M., H. Ernø, and V. Simonsen. 1983. Electrophoretic analysis of iso-enzymes of Mycoplasma species. Acta Vet. Scand. 24:14-33.

49. Schweighardt, H., P. Pechan, E. Lauermann, and G. Krassnig. 1989. Mycoplasma capricolum-infection beim alpensteinbock (Capra ibex ibex)-eine fallbeschreibung. Kleintierpraxis 34: 297-299.

50. Swanepoel, R., S. Efstratiou, and N. K. Blackburn. 1977. Mycoplasma capricolum associated with arthritis in sheep. Vet. Rec. 101:446-447.

51. Taoudi, A., and H. Kirchhoff. 1986. Isolation of Mycoplasma capricolum from cows with mastitis. Vet. Rec. 119:247.

52. Taylor, T. K., J. B. Bashiruddin, and A. R. Gould. 1992. Relationships between members of the Mycoplasma mycoides cluster as shown by DNA probes and sequence analysis. Int. J. Syst. Bacteriol. 42:593-601.

53. ter Laak, E. A. 1991. Identification of mycoplasma F38 biotype. Vet. Rec. 129:295.

54. Tully, J. G., M. F. Barile, D. G. ff. Edward, T. S. Theodore, and H. Ernø. 1974. Characterization of some caprine mycoplasmas, with proposals for new species, Mycoplasma capricolum and Mycoplasma putrefaciens. J. Gen. Microbiol. 85:102-120.

55. Wamwayi, H. M., J. S. Wafula, J. K. Litamoi, and E. N. Nandokha. 1989. Detection of antibody to mycoplasma F38 in goat sera by an enzyme-linked immunosorbent assay. Trop. Anim. Health Prod. 21:43-49.

56. Whitcomb, R. F. 1983. Culture media for spiroplasmas. Methods Mycoplasmol. 1:147-158.

57. Whitley, J. C. 1991. Ph.D. thesis. University of Melbourne, Melbourne, Australia. 